scientific research, care and treatment in the area of mental retardation. Major research projects have been established at Johns Hopkins University, Massachusetts General Hospital, Harvard University, Stanford University, the University of Wisconsin, George Peabody College, and the Kennedy Memorial Hospital in Brighton, Massachusetts. Educational, diagnostic and treatment centres are located in New York City, Washington, Chicago, and Santa Monica, California. In 1962 , a programme of International Awards was instituted by the Foundation to recognize outstanding contributions in the field of mental retardation and to support activities in this field. Awards are made in three general 'areas': (I) Scientific Research Award, to an investigator who has made outstanding contributions to the knowledge of mental retardation in the biological and behavioural sciences; (2) Service Award, to the individual or group developing outstanding programmes in the identification, care, rehabilitation, or education of the mentally retarded; (3) Leadership Award, to a civic leader, public official, author, or any other person whose activities on behalf of the mentally retarded have awakened the public conscience or led to increased individual and community effort. Awards will be in amounts of 5,000-25,000 dollars. In addition, up to 50,000 dollars will be awarded for the furtherance of current or proposed programmes. More than one Award may be offered in a single 'area'. Institutions, organizations, and individuals working in the field of mental retardation are invited to send nominations to the Foundation. These nominations should include biographical information, curriculum vitae, bibliography, and all pertinent supporting data. Nominations received by August 1 will be considered for the current year's Awards, which will be announced in December. Further information can be obtained from International Awards, the Joseph P. Kennedy, Jr. Foundation, $1413 \mathrm{~K}$ Street, N.W., Suite 306, Washington 5, D.C., to which nominations should be sent.

1963 Awards

Prof. L. S. Penrose, Galton professor of eugenics, the Galton Laboratory, University College, London, has been awarded the Scientific Research Award. The Service Award is to be shared by Dr. R. P. L. Lafon (Montpellier) and Dr. G. F. Powers (Yale). Senator Lister Hill (Alabama), Representative J. E. Fogarty (Rhode Island) and Governor B. T. Combs (Kentucky) are to share the Leadership Award.

\section{Bursary for British Women Engineers}

THe Caroline Haslett Memorial Trust is offering a bursary to assist the representation of British women engineers at the first International Conference of Women Engineers to be held in New York in June 1964. The sum of $£ 250$ will be made available for this purpose, and will be awarded to a British woman engineer, or will be shared by two, depending on the decision of the interviewing panel. Application forms can be obtained from the Socretary, Caroline Haslett Memorial Trust, 25 Foubert's Place, London, W.1, and should be completed and returned by January 31, 1964. Applicants should be qualified in any field of engineering or should be pursuing a recognized training in engineering. They should be prepared to make a real contribution to the Conference by reading a paper or leading a discussion, and to givo some lectures in Britain after the Conference. In 1960 the Trust sent two women engineers to study the training and employment of women engineers in the U.S.S.R.

\section{The Emmie Clough Scholarship}

THE Royal Horticultural Society is offering a scholarship provided out of a bequest from the late Mrs. Emmie Clough to enable a girl to take a course of training in horticulture which would otherwise be beyond her means.
The scholarship, valued at $£ 352$ a year, will commence in September 1964. It will be open to women between the ages of eighteen and thirty and will be tenable for two years at Studley College, Warwickshire. Candidates will be required to have attained a standard of education which will permit them to take full advantage of the course of study, and should normally have completed, or be prepared to undertake, such periods of practical training in horticulture as may be considered necessary. The form of application, which can be obtained from the Secretary, should be completed in the candidate's own handwriting and should be returned so as to reach the Secretary, Royal Horticultural Society, Vincent Square, London, S.W.1, not later than February 10, 1964.

\section{Atmospheric Radiation}

The International Radiation Commission of the International Association of Moteorology and Atmospheric Physies is holding a conference at Leningrad during August 10-15, 1964. There will be both invited and contributed papers on a wide variety of topies of current interest in the field of "Atmospheric Radiation". It is hoped to include in the programme sessions on: infra-red spectroscopy of the atmosphere; theory of radiative transfer in planetary atmospheres; energy balance of the Earth's atmosphere, including $(a)$ experimental investigations of the radiation field in the free atmosphero, and $(b)$ radiation problems as related to atmo. spheric dynamies and the general circulation; radiation climatology; surface and network instrumentation. Further information can be obtained from: Prof. J. London, Department of Astrophysics and the Atmospheric Scionces, University of Colorado, Boulder, Colorado; or Prof. M. I. Budyko, the Main Geophysical Observatory, M. Spasskoya 7, Leningrad $K-18$. Prof. Budyko is chairman of the local arrangements committee.

\section{Announcements}

Prof. E. Chargare, professor of biochemistry at the College of Physicians and Surgeons, Columbia University, has been awarded the Charles Leopold Mayer Prize of 80,000 N.F. by the French Academy of Sciences, for his work on nucleic acids.

A MEETING of the Food Group of the Society of Chemical Industry will be held in the University of Liverpool on January 16. The programme will include "Whaling" by Mr. C. E. Ash. Further information can be obtained from the Assistant Secretary, Society of Chemical Industry, 14 Belgrave Square, London, S.W.1.

A meeting of the Food Engineering Panel of the Society of Chemical Industry will be held in London on January 22. The programme will include "Dehydration other than A.F.D.", by Mr. G. Evans. Further information can be obtained from the Assistant Secretary, Society of Chemical Industry, 14 Belgrave Square, London, S.W.l.

A ONE-DAY symposium on "Chemical and Nutritional Aspects of Heated Fats", arranged jointly by the Oils and Fats Group and the Food Group of the Society of Chemical Industry, will be held at the Imperial College of Science and Technology, London, on March 25. Further information can be obtained from the Assistant Secretary, Society of Chemical Industry, 14 Belgrave Square, London, S.W.I.

THE one hundred and thirty-fourth course of Christmas lectures for young people will be delivered by Prof. Ronald King on "Energy". The lectures will include: "Energy in Atoms and Moles" (December 31); "Electrical Energy and Magnetism" (January 2); "Energy in Waves" (January 4); "Energy Deep Inside the Atom" (January 7); "Persuading Energy to do the 'Right' Thing" (January 9). Further information can be obtained from the Royal Institution, 21 Albemarle Street, London, W.1. 